\title{
Performance of Arbuscular Mycorrhiza Inoculated Acacia mangium Seedlings on Degraded Land with Different Rates of Phosphorus
}

\author{
MAbdus Satter ${ }^{1 *}$, M Musa Hanafi ${ }^{2}$, Tenku MM Mahmud ${ }^{2}$ and Hashim Azizah ${ }^{2}$ \\ ${ }^{1}$ Soil Science Division, Bangladesh Agricultural Research Institute (BARI), Joydebpur, Gazipur 1701, Bangladesh, ${ }^{2}$ Faculty of Agriculture, University \\ Putra Malaysia (UPM), Serdang, Selangor, Malaysia
}

[Received 08 May 2006; Accepted 21 April 2007]

\begin{abstract}
The experiment was conducted in the degraded ex-tin mining farm of Universiti Putra Malaysia during November 1998 to May 1999. The experiment was laid out in split plot design with three replications. Three phosphorus (P) rates, viz., 0, 50 and $100 \mathrm{~g}$ Gaphsa phosphate rock (GPR) per plant in combination with and without arbuscular mycorrhiza (AM) inoculation were studied on newly planted tree species Acacia mangium. Mycorrhiza inoculation was assigned to the main plot and $\mathbf{P}$ dose to the subplot. Three-month-old AM preinoculated seedlings were planted in the field at $2 \mathrm{~m} \times 2 \mathrm{~m}$ spacing. The experiment was continued until 160 days after planting (DAP). Mycorrhiza inoculation and rate of $P$ application significantly influenced growth and development of the A. mangium plants. The highest growth of un-inoculated A. mangium plants was observed with $100 \mathrm{~g}$ GPR per plant; whereas for AM inoculated plants the highest growth was observed with $50 \mathrm{~g}$ GPR per plant. This indicates that $P$ requirement of newly planted $A$. mangium plants on degraded ex-tin mining land could be reduced to $50 \mathrm{~g}$ GPR per plant, i.e., by $50 \%$ with AM inoculation.
\end{abstract}

Keywords: Arbuscular mycorrhiza, Acacia mangium, Degraded land, Phosphorus

\section{Introduction}

Degraded ex-tin mining land covers vast areas in the tropics. Highly weathered acid soils in the tropics including ex-tin mining soils are widely deficient in phosphorus (P). Phosphorus applied to these soils is rapidly transformed into low solubility Al- or Febound P. Up to $80 \%$ of the applied P might be lost because of transformation into such insoluble forms ${ }^{1}$. Due to inefficient utilization of soluble superphosphates by plants in these soils, less soluble and less expensive phosphate rocks (PRs) have been suggested for crop production ${ }^{2}$. Uptake of $\mathrm{P}$ from PRs might be improved through combined application with $\mathrm{AM}^{3}$.

The AM fungi are beneficial fungi forming symbiotic association with roots of the most plant species. The external AM hyphae extend several centimetres from the infected root surface and help in exploration of greater soil volume to absorb more nutrients and moisture from the soil. Besides, they increase the rate of photosynthesis of the host plants. They also enhance production of growth regulating substances in the host plants ${ }^{4}$. They improve $\mathrm{P}$ uptake from less soluble sources like phosphate rock (PR). They also help legumes in improving biological $\mathrm{N}_{2}$-fixation through improved $\mathrm{P}$ nutrition ${ }^{5}$. Furthermore, they help plants in uptake of other nutrients as well ${ }^{6}$. Available reports suggest that low P level increases AM colonization and hence growth and nutrition of plants. On the other hand, high P levels decrease root colonization, with plants having little or even no benefits out of mycorrhizal inoculation ${ }^{7}$. There are also evidences that under high soil $\mathrm{P}$ conditions AM can become parasitic and hence depress yield ${ }^{8}$. Soil $\mathrm{P}$ level and rate of $\mathrm{P}$ application are therefore crucial in influencing AM association and deriving benefits there of. Gafsa phosphate rock (GPR) in combination with AM was found to produce almost equivalent biomass of $A$. mangium seedlings to those with combined application of TSP and AM on the degraded ex-tin mining soils ${ }^{9}$. Such information suggest further study on determining optimum $\mathrm{P}$ dose (from GPR) for A. mangium seedlings grown on degraded ex-tin mining land. The present study was therefore undertaken to observe the effect of different $P$ rates (from GPR) with and without AM inoculation on the growth performance of A. mangium in the degraded ex-tin mining land.

\section{Materials and Methods}

The experiment was conducted in the degraded ex-tin mining farm of Universiti Putra Malaysia during November 1998 to May 1999. The soil was deficient in phosphorus, potassium and magnesium; and calcium content was at the critical level. Organic matter content and soil $\mathrm{pH}$ was low. The physical and chemical characteristics of the soil are presented in Table 1. 
Table 1. Initial physical and chemical properties of soils of the experimental field

\begin{tabular}{lcccc}
\hline Soil variable & Content & Soil variable & Content & Critical level \\
\hline Sand $(\%)$ & 79.30 & $\mathrm{~K}(\mathrm{meq} / 100 \mathrm{~g})$ & 0.12 & 0.2 \\
Silt $(\%)$ & 14.60 & $\mathrm{Ca}(\mathrm{meq} / 100 \mathrm{~g})$ & 2.35 & 2.0 \\
Clay $(\%)$ & 6.10 & $\mathrm{Mg}(\mathrm{meq} / 100 \mathrm{~g})$ & 0.18 & 0.8 \\
$\mathrm{pH}\left(\mathrm{H}_{2} \mathrm{O}\right)$ & 5.56 & $\mathrm{CEC}(\mathrm{meq} / 100 \mathrm{~g})$ & 2.37 & - \\
Organic C $(\%)$ & 0.75 & $\mathrm{Zn}(\mathrm{ppm})$ & 13.11 & 2.0 \\
$\mathrm{~N}(\%)$ & 0.09 & $\mathrm{Cu}(\mathrm{ppm})$ & 38.27 & 1.0 \\
$\mathrm{P}(\mathrm{ppm})($ Bray $\mathrm{II})$ & 7.36 & $\mathrm{Mn}(\mathrm{ppm})$ & 17.27 & 5.0 \\
\hline
\end{tabular}

The experiment was laid out in split plot design with three replications. Three P rates, viz., 0, 50 and $100 \mathrm{~g}$ GPR per plant in combination with AM and without AM were studied. Gafsa phosphate rock (GPR) containing 13\% $\mathrm{P}$ was used as the source of P. Mycorrhiza inoculation was assigned to the main plot and $\mathrm{P}$ dose to the subplot. Seedlings of A. mangium were raised in black polythene bags containing $1 \mathrm{~kg}$ fumigated tin-tailing sand. For AM treatment, the seedlings were inoculated with $50 \mathrm{~g}$ of mixed AM inoculum per bag per seedling. The seeds were inoculated with Rhizobium irrespective of AM and P treatments. Seedlings were transplanted to the field at the age of three months. The unit plots measured $8 \mathrm{~m} \times 10 \mathrm{~m}$. Pits of $0.5 \mathrm{~m} \times 0.5 \mathrm{~m} \times 0.5 \mathrm{~m}$ size were dug at $2 \mathrm{~m} \times 2 \mathrm{~m}$ spacing. Fertilizers were applied into the pits. Phosphorus fertilizer was applied as per treatment. The other fertilizers were applied as blanket dose at the rate of 60, 20, 40 and $1 \mathrm{~g}$ per pit of MP, gypsum, dolomite and manganese chloride, respectively. Fertilizers were mixed well with the soils of the pits before refilling.

Seedlings were planted during the fourth week of November 1998, seven days after pit preparation. No additional AM inoculum was applied during planting seedlings. A life-saving irrigation was given at three days after planting. The land was covered with polythene mulch for controlling weeds. Side shoots were plucked weekly up to $2 \mathrm{~m}$ plant height. The experiment was continued until 160 days after planting (DAP). Data on plant

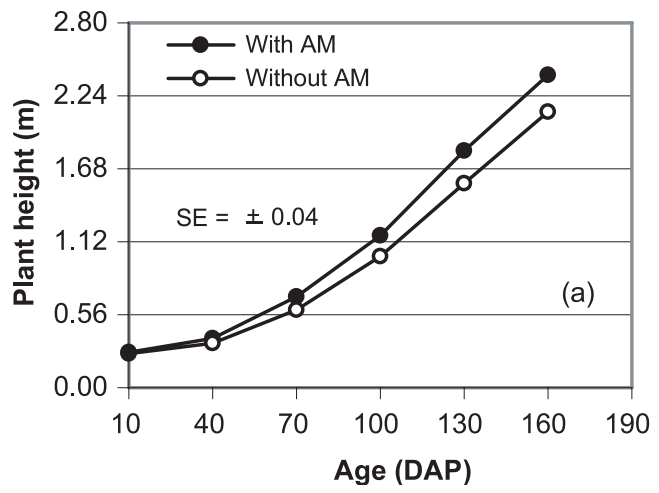

height and basal diameter (at $10 \mathrm{~cm}$ above ground level) were measured from all 20 plants in each plot at 10, 40, 70, 100, 130 and 160 DAP. Spad values were measured on the five randomly selected youngest fully expanded leaves from five plants per plot. At 150 DAP, root samples were collected from five randomly selected plants per plot. Rhizosphere soil samples of the same plants were also collected for counting AM spores. Five subsamples around each plant were collected, bulked and mixed thoroughly to make a composite sample. To assess AM infection, roots were processed after Koske and Gemma ${ }^{10}$ and observed under compound microscope. A total of 100 readings were taken per sample and the infection was expressed in percentage. Spore numbers in rhizosphere soil were determined by wet sieving and decanting method ${ }^{11}$. Data were analyzed using statistical package MSTAT-C ${ }^{12}$.

\section{Results and Discussion}

\section{Plant growth}

Height and basal diameter growth of A. mangium on degraded ex-tin mining land was significantly influenced by AM inoculation and rate of $\mathrm{P}$ application. Interaction effect of AM inoculation and age of plant was significant both on plant height and basal diameter growth of A. mangium (Figure 1). Height and basal diameter growth of AM inoculated and un-inoculated plants were identical until 70 DAP but became significantly different from 100 DAP onwards. Interaction effect of AM and P dose on the plant height and basal diameter growth of A. mangium was also significant. The AM inoculated plants given $50 \mathrm{~g}$ GPR per plant produced significantly higher plant height $(1.23 \mathrm{~m})$ and basal diameter $(1.47 \mathrm{~cm})$ compared to those with other treatments (Table 2). The AM inoculated plants given 0, 50 and $100 \mathrm{~g}$ GPR per plant produced 1.12, 1.26 and 1.05 times higher plant height and 1.16, 1.27 and 1.08 times higher basal diameter, respectively over those of un-inoculated plants. Interaction effect of AM inoculation, rate of $\mathrm{P}$ application and plant age on the height and basal diameter growth of A. mangium was not found significant.

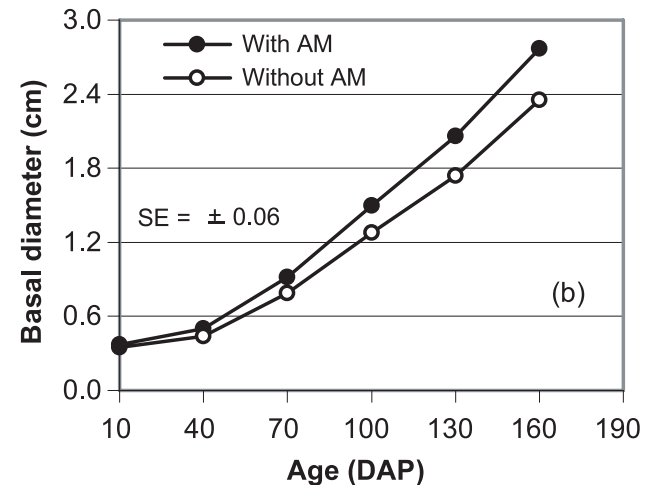

Figure 1. Interaction effect of arbuscular mycorrhiza (AM) and plant age on (a) plant height and (b) basal diameter of Acacia mangiumon degraded ex-tin mining land. DAP = Days after planting 
Table 2. Interaction effect of arbuscular mycorrhiza (AM) and phosphorus $(P)$ dose on the height and basal diameter of Acacia mangium on degraded ex-tin mining land

\begin{tabular}{lccccc}
\hline $\begin{array}{l}\text { P dose }(\mathrm{g} \text { GPR } \\
\text { per plant })\end{array}$ & \multicolumn{2}{c}{ Plant height $(\mathrm{m})$} & & \multicolumn{2}{c}{ Basal diameter $(\mathrm{cm})$} \\
\cline { 2 - 3 } \cline { 5 - 6 } & With AM & Without AM & & With AM & Without AM \\
\hline 0 & $1.02^{\mathrm{bcd}}$ & $0.91^{\mathrm{d}}$ & & $1.21^{\mathrm{cd}}$ & $1.04^{\mathrm{e}}$ \\
50 & $1.23^{\mathrm{a}}$ & $0.97^{\mathrm{cd}}$ & & $1.47^{\mathrm{a}}$ & $1.16^{\mathrm{d}}$ \\
100 & $1.12^{\mathrm{ab}}$ & $1.06^{\mathrm{bc}}$ & & $1.38^{\mathrm{b}}$ & $1.27^{\mathrm{c}}$ \\
F-test & \multicolumn{3}{c}{$*$} & & \multicolumn{2}{c}{$* *$} \\
\hline
\end{tabular}

In a column, the figures having common letter/s do not differ significantly at 1 and $5 \%$ level of probability. GPR = Gapsha phosphate rock

Height and basal diameter growth indicates that $100 \mathrm{~g}$ GPR per plant may not be sufficient for un-inoculated A. mangium plants. But for the inoculated plants, $100 \mathrm{~g}$ GPR per plant might probably stretched beyond the threshold level for optimum mycorrhizal activity. Because high P level is reported to be detrimental to AM activity and hence growth of pants ${ }^{7}$. Several evidences on the growth enhancement of different tree species with AM inoculation under field conditions are also available ${ }^{13-14}$.

\section{Spad value}

Effect of AM inoculation and rate of $P$ application on spad value of A. mangium leaves has been presented in Figure 2. Rate of $\mathrm{P}$ application and AM inoculation also significantly influenced spad value of the leaves of $A$. mangium grown on degraded ex-tin mining land. Effect of AM inoculation on spad value of A. mangium leaves was found significant. Spad value of AM inoculated plants (45) was significantly higher than that of un-inoculated plants (41). Rate of P application also had significant $(p \leq 0.05)$ effect on spad value of $A$. mangium leaves. Acacia mangium plants given 50 and $100 \mathrm{~g}$ GPR per plant produced same spad value (50), which was significantly higher than that of control plants (40). Interaction effect of AM inoculation and rate of $\mathrm{P}$ application on spad value of Acacia mangium leaves was not found significant.

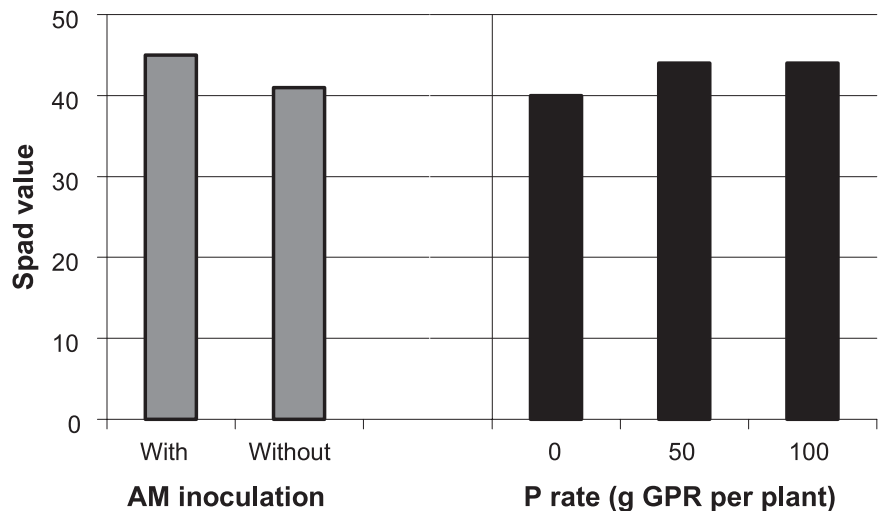

Figure 2. Effect of arbuscular mycorrhiza (AM) inoculation and phosphorus $(P)$ rate on the spad value of Acacia mangium leaves.

Spad value is known to be an indirect measurement of chlorophyll content which indicates the photosynthetic efficiency of a leaf ${ }^{15}$. The inoculated plants in the present study had higher spad value enhancing higher photosynthesis and thereby higher biomass production. It was observed in a previous study that $A$. mangium leaves with higher spad values had higher photosynthetic efficiency ${ }^{9}$. A positive relationship between spad reading and concentrations of total extracted chlorophyll in citrus leaves has been documented ${ }^{16}$. Reports are also available describing the positive linear relationship between spad readings and leaf $\mathrm{N}$ concentrations from different crops ${ }^{17-18}$. Aguilera-Gomez et al. ${ }^{19}$ (1999) reported that low P depresses net photosynthetic rate, stomatal conductance, $\mathrm{P}$ use efficiency and internal $\mathrm{CO}_{2}$ concentration; and AM could improve all these physiological variables through improving P nutrition.

\section{Mycorrhizal development}

Interaction effect of AM inoculation and rate of $\mathrm{P}$ application on root colonization and spore population in rhizosphere soils of A. mangium was found significant (Table 3). Mycorrhizal colonization in the roots of inoculated plants given 0 and $50 \mathrm{~g}$ GPR per plant (63 and 61\% respectively) was identical and superior to that with $100 \mathrm{~g}$ GPR per plant (47\%). Un-inoculated plants also had some root colonization (12 to 18\%) with the native AM fungi, which was much lower than that of AM inoculated plants. Spore population in the rhizosphere soils also followed similar trend as of root colonization with different rates of $\mathrm{P}$ application and $\mathrm{AM}$ inoculation.

Table 3. Interaction effect of AM inoculation and $P$ rate on root colonization and spore population in rhizosphere soils of Acacia mangium on degraded land

\begin{tabular}{lccccc}
\hline P dose (g GPR & \multicolumn{2}{c}{ Root colonization (\%) } & & \multicolumn{2}{c}{ Spore (No. per 10 g soil) } \\
\cline { 2 - 3 } \cline { 5 - 6 } per plant) & With AM & Without AM & & With AM & Without AM \\
\hline 0 & $63^{\mathrm{a}}$ & $18^{\mathrm{c}}$ & & $58^{\mathrm{a}}$ & $19^{\mathrm{c}}$ \\
50 & $61^{\mathrm{a}}$ & $18^{\mathrm{c}}$ & & $56^{\mathrm{a}}$ & $21^{\mathrm{c}}$ \\
100 & $47^{\mathrm{b}}$ & $12^{\mathrm{c}}$ & $37^{\mathrm{b}}$ & $15^{\mathrm{c}}$ \\
F-test & & $* *$ & & \multicolumn{2}{c}{$* *$}
\end{tabular}

In a column, the figures having common letter/s do not differ significantly at 1 and $5 \%$ level of probability. GPR = Gapsha phosphate rock

Results from this study is in consistent with the well-known fact that high P levels depress AM colonization wile low P levels enhance AM colonization and enhance growth and nutrition of plants accordingly ${ }^{20-21}$. Ammijee et al. ${ }^{22}$ suggest that the mechanism by which AM colonization is reduced could be related to anatomical changes of the root, making it resistant to fungal penetration by high $\mathrm{P}$ concentration. They also suggested that the decline in response to AM colonization is due to a combination in reduction of AM colonization as soil P increases, and the decline in the response of the plant to added $\mathrm{P}$.

\section{Tissue nutrient content}

Effect of AM inoculation was significant on $\mathrm{N}$ and $\mathrm{P}$ content but not on $\mathrm{K}, \mathrm{Ca}$ and $\mathrm{Mg}$ content (Table 4). The inoculated plants had significantly higher leaf tissue $\mathrm{N}$ and $\mathrm{P}$ content (3.90 and $0.43 \%$ respectively) compared to un-inoculated plants (3.38 and $0.38 \%$ respectively). Though leaf tissue content of $\mathrm{K}, \mathrm{Ca}$ and $\mathrm{Mg}$ was 
not significant, the inoculated plants had higher concentrations of these nutrients compared to the inoculated plants. Effect of rate of $\mathrm{P}$ application was significant only on leaf tissue $\mathrm{P}$ content (Table 4). Leaf tissue P content of plants given 50 and $100 \mathrm{~g} \mathrm{GPR}$ per plant ( 0.41 and $0.44 \%$ respectively) was identical and significantly higher than those of control plants $(0.35 \%)$. Leaf tissue content of $\mathrm{N}, \mathrm{K}$ and $\mathrm{Ca}$, though not significant, increased consistently with gradual increase in the rate of $\mathrm{P}$ application from 0 to $100 \mathrm{~g}$ GPR per plant. But $\mathrm{Mg}$ content did not follow any trend with different rates of $\mathrm{P}$ application. Interaction effect of $\mathrm{AM}$ inoculation and rate of $\mathrm{P}$ application on leaf tissue nutrient content was not found significant.

Table 4. Effect of arbuscular mycorrhiza (AM) and $P$ dose on macro-nutrient content of Acacia mangium leaves

\begin{tabular}{lccccc}
\hline Treatment & \multicolumn{5}{c}{ Nutrient content (\%) } \\
\cline { 2 - 6 } & $\mathrm{N}$ & $\mathrm{P}$ & $\mathrm{K}$ & $\mathrm{Ca}$ & $\mathrm{Mg}$ \\
\hline Mycorrhiza (M) & & & & & \\
With M & 3.90 & 0.43 & 1.02 & 0.66 & 0.22 \\
Without M & 3.38 & 0.38 & 0.83 & 0.59 & 0.21 \\
F-test & $*$ & $*$ & $\mathrm{NS}$ & $\mathrm{NS}$ & $\mathrm{NS}$ \\
P dose (g GPR per plant) & & & & & \\
0 & 3.43 & 0.35 & 0.78 & 0.54 & 0.22 \\
50 & 3.65 & 0.41 & 0.97 & 0.66 & 0.21 \\
100 & 3.84 & 0.44 & 1.02 & 0.67 & 0.22 \\
LSD $(0.05)$ & $\mathrm{NS}$ & 0.04 & $\mathrm{NS}$ & $\mathrm{NS}$ & $\mathrm{NS}$ \\
\hline
\end{tabular}

NS $=$ Not significant; GPR $=$ Gapsha phosphate rock

Lower growth of mycorrhizal plants usually under high $\mathrm{P}$ fertilization and reduced photosynthetic conditions has been reported by several authors ${ }^{7,20}$. Abbott and Robson ${ }^{23}$ suggested competition between endophyte and the host plant for carbohydrates as the possible reasons for such yield depression. Callow et al. ${ }^{24}$ stated that when $\mathrm{P}$ is not limiting for plant growth, (and perhaps when it is in excess), nor $\mathrm{P}$ will be available for carbohydrate phosphorylation, which is fundamental for active carbon transport from the host to the endophyte. Therefore, at higher soil P levels, active carbon transport can possibly proceed at higher rates, resulting in greater carbon drain from the host.

Potassium nutrition is also directly related to carbohydrate production, transport and utilization. Potassium content of inoculated plants in the current study increased steadily with increase in P level up to $100 \mathrm{~g}$ GPR per plant. Perhaps the combination of high tissue $\mathrm{P}$ and $\mathrm{K}$ concentration can interfere with the carbohydrate metabolism in a way that reduces carbohydrate utilization by the host plant, while allowing more carbon to be transported to the endophyte ${ }^{25}$. Higher $\mathrm{P}$ dose given to $A$. mangium plants, increased $\mathrm{P}$ and $\mathrm{K}$ concentrations possibly to a point at which there is an inhibition on the growth promoting ability of the AM fungi, resulting in growth depression ${ }^{25}$.

From the results it is evident that growth and development of A. mangium plants grown on degraded ex-tin mining land could be enhanced significantly with AM inoculation. The highest growth of un-inoculated $A$. mangium plants was observed with 100 g GPR per plant; whereas for AM inoculated A. mangium plants the highest growth was observed with $50 \mathrm{~g}$ GPR per plant. This indicates that $\mathrm{P}$ requirement of newly planted $A$. mangium plants on degraded ex-tin mining land could be reduced to $50 \mathrm{~g}$ GPR per plant, i.e., by 50\% with AM inoculation.

\section{References}

1. Lopez-Bucio J, de la Vega OM, Guevara-Garcia A \& Herrera-Estrella L. 2000. Enhanced phosphorus uptake in transgenic tobacco plants that overproduce citrate. Nature Biotechnol. 18: 450-453.

2. Zaharah AR, Zulkifli H \& Sharifuddin HAH. 1997. Evaluating the efficiency of different phosphate fertilizer sources for oil palm seedlings. Nutr Cycl Agroecosyst. 47: 93-98.

3. Guissou T, Ba AM, Guinko S, Duponnois R \& Plenchette C. 1999. Rock phosphate and vesicular-arbuscular mycorrhiza effects on growth and mineral nutrition of Zizyphus mauritiana Lam in an alkaline soil. Ann Sci For. 55: 925-931.

4. Danneberg G, Latus C, Zimmer W, Hundes Hagen B, Schneider-Poetsch H \& Bothe H. 1992. Influence of vesicular-arbuscular mycorrhiza on phytohormone balances in maize (Zea mays L). J Plant Physiol. 141: 33-39.

5. De la Cruz RE, Manalo MQ, Aggangan NS \& Tanbalo JD. 1988. Growth of three legume trees inoculated with VA mycorrhizal fungi and Rhizobium. Plant Soil. 108: 111-115.

6. Marschner H \& Dell B. 1994. Nutrient uptake in mycorrhizal symbiosis. Plant Soil. 159: 89-102.

7. Fries LLM, Pakovsky RS, Safir GR \& Kaminski J. 1998. Phosphorus effect on phosphatase activity in endomycorrhizal maize. Physiol Plant. 103: 162-171.

8. Graham JH \& Eissenstat DM. 1998. Field evidence for the carbon cost of citrus mycorrhizas. New Phytol. 140: 103-110.

9. Satter MA. 2000. The arbuscular mycorrhiza and phosphate rock in rehabilitation of tin tailings with Acacia mangium and peanut agroforestry system. PhD Thesis. Faculty of Agriculture, Universiti Putra Malaysia, Serdang, Malaysia.

10. Koske RE \& Gemma JN. 1989. A modified procedure for staining roots and detect VA mycorrhizas. Mycol Res. 92: 486-505.

11. Gerdemann JW \& Nicolson TH. 1963. Spores of mycorrhizal endogone extracted from soil by wet sieving and decanting. Trans $\mathrm{Br}$ Mycol Soc. 46: 235-244.

12. Michigan State University. 1989. User's Guide to MSTAT-C. Michigan State University, East Lansing, Michigan.

13. Setua GC, Kar R, Satpathy B, Das NK, Ghosh JK \& Saratchandra B. 1999. Effect of vesicular arbuscular mycorrhiza on growth, leaf yield and phosphorus uptake in mulberry (Morus alba) under irrigated, alluvial soil conditions. Indian J Agric Sci. 69: 833-836.

14. Rajan SK, Reddy BJD \& Bagyaraj DJ. 1999. Screening of arbuscular mycorrhizal fungi for their symbiotic efficiency with Tectona grandis. For Ecol Manage. 126: 91-95.

15. Sarkar RK, Saha A, Yamagishi Y \& Saha A. 1998. Leaf positional changes in the rate of photosynthesis and specific leaf weight, chlorophyll, nitrogen content and their relationship in rice. Indian $J$ Plant Physiol. 3: 135-139.

16. Duce P, Arca B, Spano D, Ventura A \& Usai I. 1997. A non-destructive instrument to determine chlorophyll content: applicability to citrus. Italus Hortus. 4: 26-31.

17. Wu FB, Wu LH \& Xu FH. 1998. Chlorophyll meter to predict nitrogen sidedress requirements for short-season cotton (Gossypium hirsutum L). Field Crops Res. 56: 309-314. 
18. Shapiro CA. 1999. Using a chlorophyll meter to manage nitrogen applications to corn with high nitrate irrigation water. Commun Soil Sci Plant Anal. 30: 7-8.

19. Aguilera-Gomez L, Davies FT, Olalde-Portugal V, Duray SA \& Phavaphutanon L. 1999. Influence of phosphorus and endomycorrhiza (Glomus intraradices) on gas exchange and plant growth of chile ancho pepper (Capsicum annum L cv San Luis). Photosynthetica. 36: 441-449.

20. Siqueira JO, Saggin Junior OJ, Flores Aylas WW \& Guimaraes PTG. 1998. Arbuscular mycorrhizal inoculation and superphosphate application influence plant development and yield of coffee in Brazil. Mycorrhiza. 7: 293-300.

21. Olsen JK, Schaefer JT, Edwards DG, Hunter MN, Galea VJ \& Muller LM. 1999. Effects of a network of mycorrhizae on capsicum
(Capsicum annuum L) grown in the field of five rates of applied phosphorus. Aust J Agric Res. 50: 239-252.

22. Ammijee F, Stribley DP \& Tinker PB. 1990. Soluble carbohydrates in the roots of leek (Allium porrum) plants in relation to phosphorus supply and VA mycorrhiza. Plant Soil. 124: 195-198.

23. Abbott LK \& Robson AD. 1986. The effect of mycorrhiza on plant growth. In VA Mycorrhiza (Powell CLL \& Bagyaraj DJ eds), $2^{\text {nd }}$ edn, pp 113-130. CRC Press, Boca Raton, Florida.

24. Callow JA, Capacio LCM, Parish G \& Tinker PB. 1978. Detection and estimation of photosynthate in vesicular arbuscular mycorrhizas. New Phytol. 80: 125-134.

25. Antunes V \& Cardoso EJBN. 1991. Growth and nutrient status of citrus plants as affected by mycorrhiza and phosphorus application. Plant Soil. 131: 11-19. 


\title{
Antimicrobial Activity of Cinnamomum tamala Essential Oil and Its Composition and Toxicity on White Strain Rats
}

\author{
Jaripa Begum $^{1 *}$, Shoma Dutta ${ }^{1}$, Mohammad Yusuf ${ }^{1}$, Jashim Uddin Chowdhury ${ }^{1}$, Kabir Ahmed ${ }^{1}$, Salauddin Ahmed ${ }^{2}$ \\ and M Nural Anwar ${ }^{2}$ \\ ${ }^{1}$ Bangladesh Council of Scientific \& Industrial Research (BCSIR) Laboratories, Chittagong, Chittagong 4220, Bangladesh, ${ }^{2}$ Department of \\ Microbiology, University of Chittagong, Chittagong 4331, Bangladesh
}

[Received 09 October 2006; Accepted 21 April 2007]

\begin{abstract}
The antimicrobial activity of the essential oil from the leaves of Cinnamomum tamala grown at Hathazari, Chittagong was evaluated with pathogenic bacteria and phytopathogenic fungi. The aim of this study was also determine the composition of the oil and to estimate medium lethal doses $\left(L_{50}\right)$ of the oil after oral and intraperitoneal administration in mice. The oil was found to be very effective against all Gram-positive and Gram-negative bacterial strains tested even at very low concentration $(2 \mu \mathrm{l} / \mathrm{disk})$. The highest zone of inhibition was recorded with Bacillus subtilis, followed by Shigella sonnei $(26 \mathrm{~mm})$ at a concentration of $20 \mu \mathrm{l} /$ disc. The oil also exhibited potent antifungal activity. The minimum concentration for absolute inhibition (MCAI) of Fusarium equiseti was found to be $250 \mathrm{ppm}$, followed by Colletotrichum corchori and Alternaria alternata (500 ppm). Botryodiplodia theobromae and Drechslera oryzae showed moderate sensitivity (MCAI $750 \mathrm{ppm}$ ) to the oil, while Curvularia lunata was found to least sensitive (MCAI 1,250 ppm). The leaf oil was analyzed by gas chromatograph-mass spectrometer (GC-MS). It contained 67 components representing $\mathbf{9 9 . 4 5 \%}$ of the total oil constituents. The major components were eugenol $(39.57 \%)$, gamma-terpinene $(12.25 \%)$ and patchouli oil $(\mathbf{1 0 . 7 3 \% )}$. Acute toxicity test of the essential oil had been carried out on white strain rats. The oil administered orally at the rate of $2 \mathrm{ml} / \mathrm{kg}$ body weight showed no gross toxicity in rats and $\mathrm{LD}_{\mathbf{5 0}}$ was found to be $7.94 \mathrm{mg} / \mathrm{kg}$ body weight based on intraperitoneal administration. The essential oil of the plant presented here showed very promising activity in the area of antimicrobial agents, warranting further investigation.
\end{abstract}

Keywords: Essential oil, Cinnamomum tamala leaves, Antimicrobial activity, Minimum concentration for absolute inhibition (MCAI), Oil composition, Toxicity, Lethal doses $50\left(\mathrm{LD}_{\mathbf{5 0}}\right)$

\section{Introduction}

The use of plant extracts and phytochemicals, both with known antimicrobial properties, can be of great significance in therapeutic treatments. In the last few decades, a number of studies have been conducted in different countries to prove such efficiency ${ }^{1}$. Many plants have been used because of their antimicrobial traits, which are due to compounds synthesized in the secondary metabolism of the plant. These products are known by their active substances, for example, the phenolic compounds which are part of the essential oils ${ }^{2}$, as well as in tannin ${ }^{3}$. Essential oils are responsible for the fragrance of plants. These oils are secondary metabolites that are highly enriched in compounds based on an isoprene structure ${ }^{1}$. They are called terpenes and when the compounds contain additional elements, usually oxygen, they are termed terpenoids. Terpenes or terpenoids are active against bacteria $^{4-5}$, fungi ${ }^{6-7}$, viruses $^{8}$, and protozoa ${ }^{9}$.

Cinnamomum tamala Nees (Lauraceae) leave, also called Bay leaf or Tejpata, is a spice of commerce. The plant is an evergreen, aromatic tree distributed in tropical and subtropical Himalayas and in north-eastern districts of Bangladesh. Besides flavouring agent, the leaves are reported to be stimulant, carminative, diuretic, diaphoretic, lactagogue, and hypoglycaemic used in the treatment of colic, diarrhoea, anorexia, skin diseases, sore throat, coughs, colds and in scorpion sting ${ }^{10-12}$. Search of literature reveals that many essential oils have good fungi-toxicity and bactericidal activity ${ }^{13-15}$. Essential oil of $C$. tamala leaves native to different geographical locations has been investigated for its composition ${ }^{16-19}$. However, in Bangladesh there is little information available on the composition of leaf oil of C. tamala ${ }^{20}$ and no information available on its antimicrobial properties.

The objective of this research was to evaluate the potential of essential oil of $C$. tamala leaves on pathogenic Gram-positive and Gram-negative bacteria as well as common phytopathogenic fungi. Moreover, we investigated the toxicity and composition of the essential oil.

\section{Material and Methods \\ Extraction of oil}

The leaves of Cinnamomum tamala were collected from a single tree from the Regional Agricultural Research Station, Hathazari,

*Corresponding author:

Dr. Jaripa Begum, Principle Scientific Officer, Bangladesh Council of Scientific \& Industrial Research (BCSIR) Laboratories, Chittagong, Chittagong 4220, Bangladesh Tel (Office): (031) 681763, (031) 681763; Fax: +880 (031) 682505; E-mail: ctglab@spnetctg.com 
Chittagong. Voucher specimen was deposited in the herbarium of BCSIR Laboratories, Chittagong. Fresh leaves were subjected to hydrodistillation in Clevenger apparatus ${ }^{21}$. The oil thus obtained was dried over anhydrous sodium sulphate and stored in sealed glass vials under refrigeration prior to analysis. Refractive index of the oil was measured according to standard method ${ }^{22}$.

\section{Test microorganisms}

The Gram-positive and Gram-negative bacterial cultures used as test organisms were collected from Bangladesh Type Culture Collection (BTCC), Institute of Nutrition and Food Science, University of Dhaka and Centre for Health \& Population Research, International Centre for Diarrhoeal Disease Research, Bangladesh (ICDDR,B), Mohakhali, Dhaka. Bacterial strains included Bacillus cereus BTCC 19, Bacillus subtilis BTCC 17, Staphylococcus aureus BTCC 43, Bacillus megaterium BTCC 18, Escherichia coli BTCC 12, Vibrio cholerae ICDDR, B (CRL), Salmonella typhi BTCC 97(CRL), Pseudomonas sp. BTCC 11 (CRL), Shigella dysenteriae BTCC 500 (CRL) and Shigella sonnei ICDDR,B (CRL). Phytopathogenic fungi used in this study were collected from Department of Microbiology, University of Chittagong, Chittagong. These were Alternaria alternate, Curvularia lunata, Fusarium equiseti, Colletotrichum corchori, Drechslera oryzae, Macrophomina phaseolina and Botryodiplodia theobromae.

\section{Antibacterial activity assay}

In vitro antibacterial activity of the essential oil was done by disc diffusion method ${ }^{23}$ using paper disc $(8 \mathrm{~mm}$ in diameter) and nutrient agar as basal medium. Antibacterial activities were indicated by clear zone of growth inhibition around the disc. The inhibition zones were recorded after 24 to $48 \mathrm{~h}$ of incubation at $37^{\circ} \pm 1^{\circ} \mathrm{C}$. Ampicillin $(20 \mu \mathrm{g} / \mathrm{disc})$ was used as standard antibiotic for comparison of results under identical condition.

\section{Antifungal activity assay}

In vitro antifungal activity of the essential oil was done by poison food technique ${ }^{24}$ using potato dextrose agar (PDA) as basal medium. The diameter of radial mycelial growth of the test fungi was measured after 3 to 5 days of incubation at $25 \pm 1^{\circ} \mathrm{C}$ and expressed as percent mycelial growth inhibition following the formula: $\mathrm{I}=(\mathrm{C}-\mathrm{T}) / \mathrm{C} \times 100$; where, $\mathrm{I}=$ percentage of inhibition, $\mathrm{C}=$ diameter of the fungal colony in control, $\mathrm{T}=$ diameter of the fungal colony in treatment. Nystatin (100 ppm) was used as standard antifungal antibiotic for comparison of results under identical condition.

\section{Gas chromatograph-mass spectrometer (GC-MS) analysis}

The analysis was carried out by GC-MS electron impact ionization (EI) method on GC-17 gas chromatograph (Shimadzu, Japan) coupled to a GCMS-QP5050A mass spectrometer (Shimadzu, Japan), fused silica capillary column, length $30 \mathrm{~m}$, internal diameter (ID) $0.25 \mathrm{~mm}$, inner surface coated with DB-1 (J\&W), film thickness $0.25 \mu \mathrm{m}$, column temperature $40^{\circ} \mathrm{C}$ to $250^{\circ} \mathrm{C}$ at the rate of $4^{\circ} \mathrm{C} / \mathrm{min}$, carrier gas, helium at constant pressure of $50 \mathrm{kPa}$, acquisition parameter full scan, scan range 40-350 amu. The compounds were identified using the NIST 127 and NIST 147 library data.

\section{Acute toxicity test on rats}

For oral toxicity, the essential oil was dosed orally at the rate of 2 $\mathrm{ml} / \mathrm{kg}$ body weight on 10 white strain rats ( 5 male and 5 female) weighing about 150-165 g/rat and observed for $24 \mathrm{~h}$ for any mortality and next 10 days for any delayed effect. For intraperitoneal toxicity, 60 rats weighing about 150-165 g/rat were divided into six groups. Each group received different doses of essential oil by intraperitoneal (IP) route. After the administration of different doses of essential oil, the animals were kept under observation for $24 \mathrm{~h}$. The time of death were recorded. Survived animals were observed for the $0 \%$ mortality and $100 \%$ mortality was recorded according to the formulas of Miller and Tainter ${ }^{25}$. The probit values were read from the table of probits. A graph of log dose versus probit was plotted. The dose corresponding to $50 \%$ or probit of 5 was recorded as lethal dose $50\left(\mathrm{LD}_{50}\right)$.

\section{Results and Discussion}

The leaf oil from Cinnamomum tamala, obtained with $1.0 \%$ yield value $(\mathrm{v} / \mathrm{w}$ in $\mathrm{FWB})$ having a refractive index of $1.468\left(29^{\circ} \mathrm{C}\right)$, was a light yellow mobile liquid and possessed a spicy smell. The results of the in vitro antibacterial activity of the essential oil $(2,5,10,15$ and $20 \mu 1 /$ disk $)$ against the Gram-positive and Gramnegative test bacterial strains are summarized in Table 1. It was observed that the essential oil was most effective against the test bacteria strains even at the lowest concentration ( $2 \mu 1 /$ disk $)$ of the essential oil. The highest zone of inhibition ( $32 \mathrm{~mm}$ ) was recorded against $B$. subtilis; followed by $S$. sonnei $(26 \mathrm{~mm})$ at a concentration of $20 \mu \mathrm{l} /$ disk. In some cases, the essential oil exhibited better antibacterial activity than the standard antibiotic, ampicillin. Similar antibacterial properties of a number of essential oils have been reported by different workers ${ }^{13,15,26-27}$.

Table 1. Antibacterial activity of essential oil of Cinnamomum tamala leaves

\begin{tabular}{|c|c|c|c|c|c|c|}
\hline \multirow[t]{3}{*}{ Bacterium } & \multicolumn{6}{|c|}{$\begin{array}{c}\text { Antibacterial activity } \\
\text { (Diameter of zone of inhibition in } \mathrm{mm} \text { ) }\end{array}$} \\
\hline & \multicolumn{5}{|c|}{ Essential oil ( $\mu 1 /$ disk $)$} & \multirow{2}{*}{$\begin{array}{l}\text { Ampicillin } \\
(20 \mu \mathrm{g} / \mathrm{disk})\end{array}$} \\
\hline & 2 & 5 & 10 & 15 & 20 & \\
\hline \multicolumn{7}{|l|}{ Gram-positive organisms } \\
\hline Bacillus cereus & 18 & 19 & 21 & 22 & 24 & 22 \\
\hline Bacillus megaterium & 17 & 19 & 21 & 22 & 24 & 22 \\
\hline Bacillus subtilis & 20 & 24 & 25 & 28 & 32 & 25 \\
\hline Staphylococcus aureus & 15 & 16 & 18 & 20 & 21 & 20 \\
\hline \multicolumn{7}{|l|}{ Gram-negative organisms } \\
\hline Escherichia coli & 14 & 17 & 18 & 21 & 23 & 13 \\
\hline Pseudomonas species & 15 & 20 & 21 & 22 & 24 & 19 \\
\hline Salmonella typhi & 16 & 19 & 20 & 21 & 22 & 30 \\
\hline Shigella dysenteriae & 16 & 20 & 21 & 22 & 24 & 35 \\
\hline Shigella sonnei & 18 & 21 & 24 & 25 & 26 & 30 \\
\hline Vibrio cholerae & 15 & 19 & 20 & 21 & 23 & 24 \\
\hline
\end{tabular}


The in vitro antifungal activity of the essential oil and standard antibiotic nystatin is shown in Table 2 . It was revealed from the results that the antifungal activity of the oil was remarkable; inhibiting the growth of all the 7 test fungal pathogens completely (100\%). The minimum concentration for absolute inhibition (MCAI) of the oil against $F$. equiseti was found to be $250 \mathrm{ppm}$; followed by C. corchori and A. alternata (500 ppm). B. theobromae, D. oryzae and $M$. phaseolina showed more resistance towards the oil and MCAI was found to be $750 \mathrm{ppm}$; followed by C. lunala $(1,250$ $\mathrm{ppm}$ ). At lower concentration, the oil exhibited fungistatic activity, but at MCAI it was fungicidal. It was also observed that the essential oil was more effective against the phytopathogenic fungi than those of the bacterial strains. Similar antifungal properties of a number of essential oils have been reported by several workers ${ }^{28-32}$.

Table 2. Antifungal activity of essential oil of Cinnamomum tamala leaves

\begin{tabular}{|c|c|c|c|c|c|c|c|}
\hline \multirow[t]{3}{*}{ Bacterium } & \multicolumn{7}{|c|}{$\begin{array}{c}\text { Antifungal activity } \\
\text { (Percent growth inhibition) }\end{array}$} \\
\hline & \multicolumn{6}{|c|}{ Essential oil (ppm) } & \multirow{2}{*}{$\begin{array}{r}\text { Nystatin } \\
(100 \mathrm{ppm})\end{array}$} \\
\hline & 100 & 250 & 500 & 750 & 1,000 & 1,250 & \\
\hline $\begin{array}{l}\text { Alternaria } \\
\text { alternata }\end{array}$ & 50 & 78 & 100 & 100 & 100 & 100 & 56 \\
\hline $\begin{array}{l}\text { Botryodiplodia } \\
\text { theobromae }\end{array}$ & 13 & 33 & 80 & 100 & 100 & 100 & 82 \\
\hline $\begin{array}{l}\text { Colletotrichum } \\
\text { corchori }\end{array}$ & 50 & 78 & 100 & 100 & 100 & 100 & 42 \\
\hline $\begin{array}{l}\text { Curvularia } \\
\text { lunata } \\
\text { Drechslera }\end{array}$ & 27 & 56 & 72 & 80 & 88 & 100 & 72 \\
\hline oryzae & 7 & 9 & 32 & 100 & 100 & 100 & 76 \\
\hline $\begin{array}{c}\text { Fusarium } \\
\text { equiseti }\end{array}$ & 29 & 100 & 100 & 100 & 100 & 100 & 46 \\
\hline $\begin{array}{l}\text { Macrophomina } \\
\text { phaseolina }\end{array}$ & 25 & 33 & 52 & 100 & 100 & 100 & 71 \\
\hline
\end{tabular}

The essential oil was analyzed by GC-MS and many components were identified. Some of components that might have antimicrobial properties are listed in Table 3. Sixty seven components representing $99.45 \%$ of the total leaf oil were identified. Eugenol (39.57\%), gamma terpinene (12.25\%) and patchouli oil $(0.73 \%)$ were the major components in the leaf oil. Eugenol is a wellcharacterized representative of phenolic compounds possessing a $\mathrm{C}_{3}$ side chain at a lower level of oxidation and containing no oxygen are classified as essential oils ${ }^{1}$. Eugenol is considered bacteriostatic against both fungi ${ }^{33}$ and bacteria ${ }^{34}$.

The acute toxicity test of the leaf essential oil was carried out on white strain rats, orally and intraperitoneally. The oil administered orally at the rate of $2 \mathrm{ml} / \mathrm{kg}$ body weight showed no gross toxicity in rats. The results of intraperitoneal toxicity test are presented in Table 4 . The $\mathrm{LD}_{50}$ value was found to be $794 \mathrm{mg} / \mathrm{kg}$ body weight. These results suggest the presence of bioactive plant metabolites.
Table 3. Compositions of the essential oil of Cinnamomum tamala leaves

\begin{tabular}{|c|c|}
\hline Component & Percentage \\
\hline Bornylene & 0.06 \\
\hline 3-Carene & 2.07 \\
\hline Bicyclo [3.1.0] hex-2-ene, 4-methy lene-1-(1-methy lethy 1)- & 3.26 \\
\hline Fenchene & 0.19 \\
\hline Camphene & 0.16 \\
\hline Sabinene & 0.15 \\
\hline Beta-pinene & 2.40 \\
\hline Gamma-terpinene & $12.25^{*}$ \\
\hline Cyclobytane, 1,2-bis (1-methylethenyl)-, trans- & 5.77 \\
\hline Eucalyptol & 2.44 \\
\hline 1,3,6-Octatriene,3,7-dimethy 1 -, (Z) & 1.01 \\
\hline alpha-Thujene & 0.18 \\
\hline 1,4-Cyclohexadiene, 1-methy 1-4-(1-methylethy 1$)-$ & 0.56 \\
\hline Cyclohexene,1-methyl-4-(1-methylethyl)- & 0.36 \\
\hline alpha-Terpinene & 2.84 \\
\hline Iscrotylbenzene & 0.05 \\
\hline 2-Cyclohexen-1-o1,1-methyl-4-(1methylethyl)-, cis- & 0.16 \\
\hline Cycloheptane, 1,3,5-tris(methylene)- & 0.04 \\
\hline Borneol & 0.39 \\
\hline L-4-terpineneol & 0.42 \\
\hline p-Cymen-8-o 1 & 0.81 \\
\hline Terpinyl acetate & 1.95 \\
\hline Sabinyl acetate & 0.48 \\
\hline cis-Piperitol & 0.04 \\
\hline Linalool & 0.17 \\
\hline p-Cumenol & 0.07 \\
\hline Lavaandulol & 0.18 \\
\hline Esdragole & 0.05 \\
\hline Thymol & 0.04 \\
\hline Bornly acetate & 0.09 \\
\hline Dihydroedulan IIA & 0.12 \\
\hline Elixwne & 0.13 \\
\hline Eugenol & $33.57^{*}$ \\
\hline Caryophyllene & 0.16 \\
\hline alpha-Guaiene & 0.62 \\
\hline Ethylmethy imidazole & 0.14 \\
\hline alpha-Panasinsen & 0.40 \\
\hline alpha-Patchoulene & 0.33 \\
\hline Patchoulene & 0.09 \\
\hline Germacrene D & 0.18 \\
\hline Eugenyl acetate & 6.00 \\
\hline Decahydro-8a-ethyl-2,1,4a,6-etramethylnaphthalene & 0.06 \\
\hline beta-Elemene & 0.09 \\
\hline \multicolumn{2}{|l|}{ Spiro [androst-5-ene-17, 1p-cyclobutan] } \\
\hline 2p-one, 3-hydroxy-, (3.beta., 17.beta.) & 0.06 \\
\hline Diepi-alpha-cedrene epoxide & 2.33 \\
\hline Caryophylleno oxide & 0.67 \\
\hline alpha-Guaiene & 0.13 \\
\hline Spathulenol & 0.67 \\
\hline Viridiflorol & 0.91 \\
\hline Cubenol & 0.22 \\
\hline Ledol & 1.49 \\
\hline Patchouli alcohol & $10.37^{*}$ \\
\hline Carotol & 0.14 \\
\hline alpha-Bisabolol & 0.21 \\
\hline Tetrahydroedulan & 0.93 \\
\hline trans, trans-Farnesal & 0.26 \\
\hline beta-Humulene & 0.14 \\
\hline 3-Nonen-5-one & 0.05 \\
\hline delta.-Neoclovene & 0.04 \\
\hline cis-(-)-2,4a,5,6,9-tetramethyl (IH) benzocycloheptene & 0.10 \\
\hline $3,7,11$-Trimethyl-dideca-2, 4,6,10-tetraenal & 0.13 \\
\hline \multicolumn{2}{|l|}{ 2(1H) Naphthalenone, $3,5,6,8$} \\
\hline 8a-hexahydro-4,8a-dimethyl-6-(1-methytlethenyl)- & 0.05 \\
\hline Humulen (VI) & 0.08 \\
\hline 1-Cyclohexene-1-propanal, 2,6,6-trimethyl- & 0.09 \\
\hline Corymbolone & 0.15 \\
\hline Pregnan-20-one,3-(acetyloxy)-e-hydroxy-6, & \\
\hline 16-dimethyl-,(3. beta., 5. alpha., 6.beta., 16. alpha.)- & 0.07 \\
\hline
\end{tabular}

*Major components 
Table 4. Toxicity test of the essential oil of Cinnamomum tamala leaves based on intraperitoneal (IP) administration to white strain rats

\begin{tabular}{lccccccc}
\hline Rat group & $\begin{array}{c}\text { Dose } \\
(\mathrm{mg} / \mathrm{kg})\end{array}$ & $\begin{array}{c}\text { Concentration } \\
(\mathrm{ml} / \mathrm{rat})\end{array}$ & $\begin{array}{c}\text { Dead } \\
(\mathrm{No} .)\end{array}$ & $\begin{array}{c}\text { Survived } \\
(\text { No. })\end{array}$ & $\begin{array}{c}\text { Death rate } \\
(\%)\end{array}$ & $\begin{array}{c}\text { Corrected } \\
(\%)\end{array}$ & Probit \\
\hline 1 & 1,800 & 0.25 & 10 & 0 & 100 & 97.5 & 6.97 \\
2 & 1,440 & 0.20 & 8 & 2 & 80 & 80.0 & 5.84 \\
3 & 1,080 & 0.15 & 6 & 4 & 60 & 60.0 & 5.25 \\
4 & 720 & 0.10 & 4 & 6 & 40 & 40.0 & 4.75 \\
5 & 360 & 0.05 & 2 & 8 & 20 & 20.0 & 4.61 \\
6 & 180 & 0.026 & 0 & 10 & 0 & 2.5 & 3.04 \\
\hline
\end{tabular}

The antimicrobial properties of plants have been investigated by a number of researchers worldwide. It was documented that several compounds extracted from these plants inhibited the growth of Gram-positive and Gram-negative organisms and some of them also inhibited the growth of fungi ${ }^{35-38}$. More detailed study on antimicrobial compounds was done evaluating extracts from 120 plant species from 28 different families ${ }^{39}$. It was documented that 81 extracts obtained from 58 plants were active against $S$. aureus, and five extracts from four other plants inhibited the growth of $P$. aeruginosa. Another study ${ }^{40}$ detected the antibacterial and antifungal (C. albicans) activity of essential oils obtained from Croton triangularis leaves.

Since the products of higher plant origin are reported to be biodegradable, the $C$. tamala leaf oil with its low toxicity, strong antifungal and antibacterial properties could be an excellent candidate as a natural antimicrobial agent. Although the active components in the extracts responsible for antibacterial and antifungal activities have not been identified conclusively, all of these results imply the existence of bioactive metabolites and therefore, more research with this plant is warranted.

\section{References}

1. Cowan MM. Plant products as antimicrobial agents. Clin Microbiol Rev. 12(4): 564-582.

2. Jansen AM, Cheffer JJC \& Svendsen AB. 1987. Antimicrobial activity of essential oils: A 1976-1986 literature review. Aspects of test methods. Planta Med. 40: 395-398.

3. Saxena G, McCutcheon AR, Farmer S, Towers GHN \& Hancock REW. 1994. Antimicrobial constituents of Rhus glabra. J Ethnopharmacol. 42: 95-99.

4. Barre JT, Bowden BF, Coll JC, Jesus J, Fuente VE, Janairo GC \& Ragasa CY. 1997. A bioactive triterpene from Lantana camara. Phytochemistry. 45: 321-324.

5. Habtemariam S, Gray AI \& Waterman PG. 1993. A new antibacterial sesquiterpene from Premna oligotricha. J Nat Prod. 56: 140-143.

6. Harrigan GG, Ahmad A, Baj N, Glass TE, Gunatilaka AAL \& Kingston DGI. 1993. Bioactive and other sesquiterpenoids from Porella cordeana. J Nat Prod. 56: 921-925.

7. Rana BK, Singh UP \& Taneja V. 1997. Antifungal activity and kinetics of inhibition by essential oil isolated from leaves of Aegle marmelos. J Ethnopharmacol. 57: 29-34.

8. Hasegawa H, Matsumiya S, Uchiyama M, Kurokawa T, Inouye Y, Kasai R, Ishibashi S \& Yamasaki K. 1994. Inhibitory effect of some triterpenoid saponins on glucose transport in tumor cells and its application to in vitro cytotoxic and antiviral activities. Planta Med. 6: $240-243$.

9. Ghoshal S, Prasad BNK \& Lakshmi V. 1996. Antiamoebic activity of Piper longum fruits against Entamoeba histolytica in vitro and in vivo. J Ethnopharmacol. 50: 167-170.

10. Chopra RN, Nayer SL \& Chopra IC. 1956. Glossary of Indian Medicinal Plants, pp 65-66. Council of Scientific and Industrial Research, New Delhi.

11. Yusuf. M, Chowdhury JU, Wahab MA \& Begum J. 1994. Medicinal Plants of Bangladesh, p 63. Bangladesh Council of Scientific and Industrial Research, Dhaka.

12. Ghani A. 1998. Medicinal Plants of Bangladesh: Chemical Constituents, $1^{\text {st }}$ edn, p 128. Asiatic Society of Bangladesh, Dhaka.

13. Maruzella JC \& Henry PA. 1958. The antibacterial activity of perfume oils. 47: 471-476.

14. Sinha GK \& Gulati BC.1990. Antibacterial and antifungal study of some essential oils and some of their constituents Indian Perfumer. 34(2): 126-129.

15. Begum J, Chowdhury JU, Yusuf M, Wahab MA, Ahmed K, Akter N \& Anwar MN. 1999. Antimicrobial activity of essential oils isolated from the Ocimum amricanum and O. gratissimum var. clocimum and their toxicity in white strain rats. Bangladesh J Microbiol. 16(2): 127-134.

16. Sood SP, Padha CD, Talwar YP, Jamwal RK, Chopra MM \& Rao PR. 1979. Essential oils from the leaves of Cinnamomum tamala Nees \& Eberm growing in Himachal Pradesh.Indian Perfumer. 23: 75-78.

17. Gulati BC. 1982. Essential oils of Cinnamomum species. In Cultivation and Utilization of Aromatic Plants (Atal CK \& Kapur BM eds), pp 607-619. Regional Research Laboratory (CSIR), Jammu-Tawi.

18. Nath SC, Singh RS \& Hazarika AK. 1994. Essential oil of leaves of Cinnamomum tamala Nees \& Eberm from North East India. J Spices Aromatic Crops. 3: 33-35.

19. Showkat RM, Ali M \& Kapoor R. 2004. Chemical composition of essential oil of Cinnamomum tamala Nees \& Eberm leaves. Flav Frag J. 19: 112-114.

20. Begum J, Chowdhury JU, Yusuf M \& Wahab MA. 1993. Studies on essential oils for their antibacterial and antifungal properties. Part 1. Preliminary screening of 35 essential oils. Bangladesh J Sci Ind Res. 28(4): 25-34.

21. Clevenger JF. 1928. Apparatus for the determination of volatile oil. J Am Pharm Assoc. 17: 346.

22. Whitely MA. 1947. Thorpe's Dictionary of Applied Chemistry, $4^{\text {th }}$ edn, Vol 8, p 651. Green and Co Ltd, Longmans.

23. Bauer AW, Kibry MM, Sherris JC \& Turck M. 1966. Antibiotic susceptibility testing by a standardized single disc method. Am J Clin Path. 45: 493-496.

24. Grover RK \& Moore JD. 1962. Toximetric studies of fungicides against brown rot organisms Sclerotina fructicola and S. laxa. Phytopathol. 52: 876-880. 
25. Miller LC \& Tainter ML. 1944. Estimation of the $\mathrm{ED}_{50}$ and its error by means of logarithmic-probit paper. Proc Soc Exp Biol Med. 59: 261-264.

26. Rao RSS \& Nigam SS. 1978. Chemical and antimicrobial examination of the essential oil of Nigella sativa var. aromatica. Indian Perfumer. 22(4): 232-238.

27. Chowdhury DC, Suri RK \& Deshmukh DK.1998. In vitro antimicrobial activity of essential oil of newly evolved Eucalyptus hybrid FRI-4. Indian Forester. 114(1): 35-38.

28. Thind TS \& Suri KR. 1979. In vitro antifungal efficacy of four essential oils. Indian Perfumer. 23(2): 138-140.

29. Handique AK \& Singh HB. 1990. Antifungal action of lemongrass oil on some soil born plant pathogens. Indian Perfumer. 34(3): 232234 .

30. Begum J, Chowdhury JU, Yusuf M, Wahab MA, Ahmed K, Akter N \& Anwar MN. 1997. Evolution of oils extracted from Eucalyptus citriodora and E. camaldulensis for antimicrobial properties and their toxicity in rats. Bangladesh J Sci Ind Res. 32(4): 561-566.

31. Chowdhury JU, Begum J, Yusuf M \& Wahab MA, Kamal AKMM \& Chowdhury SA. 1999. Studies on Cymbopogon flexuosus for its growth, yield performances, essential content, physicochemical characteristics and fungitoxic properties of the oil. Bangladesh J Sci Ind Res. 34(3-4): 418-421.

32. Chowdhury JU, Yusuf M, Begum J, Sultana SA \& Husain MM. 2003. Composition and fungitoxic properties of the essential oil of Lippia javanica leaves. Indian Perfumer. 47(4): 385-388.
33. Duke JA. 1985. Handbook of Medicinal Herbs. CRC Press Inc, Boca Raton, Florida.

34. Thomson WAR. 1978. Medicines from the Earth. McGraw-Hill Book Co, Maidenhead.

35. Alonso-Paz E, Cerdeiras MP, Fernandez J, Ferreira F, Moyna P, Soubes M, Vazquez A, Veros S \& Zunno L. 1995. Screening of Uruguayan medicinal plants for antimicrobial activity. J Ethnopharmacol. 45: $67-70$.

36. Anesini E \& Perez C. 1993. Screening of plants used in Argentine folk medicine for antimicrobial activity. J Ethnopharmacol. 39: 119128 .

37. Martinez MJ, Vasquez SM, Espinosa-Perez C, Dias M \& HerreraSanchez M. 1994. Antimicrobial properties of argentatine - a isolated from Parthenium argentatum. Fitoterapia. 65: 371-372.

38. Martinez MJ, Betancourt J, Alonso-Gonzalez N \& Jauregui A. 1996. Screening of some Cuban medicinal plants for antimicrobial activity. J Ethnopharmacol. 52: 171-174.

39. Santos Filho D, Sarti SJ, Bastos JK, Leitão Filho HF, Machado JO, Araujo MLC, Lopes WD \& Abreu JE. 1990. Atividade antibacteriana de extratos vegetais. Rev Cien Farm. 12: 39-46.

40. Lemos TLG, Monte FJQ, Matos FJA, Alencar JW, Craveiro AA, Barbosa RCSB \& Lima ED. 1992. Chemical composition and antimicrobial activity of essential oils from Brazilian plants. Fitoterapia. 63: 266-268. 